\title{
Lipschütz ulcers: uncommon diagnosis of vulvar ulcerations
}

\author{
Vera Mourinha, ${ }^{1}$ Sara Costa, ${ }^{2}$ Cecília Urzal, $^{2}$ Fernando Guerreiro ${ }^{2}$
}

${ }^{1}$ Department of Gynecology and Obstetrics, Centro Hospitalar do Algarve-Faro, Faro, Portugal

${ }^{2}$ Department of Gynecology and Obstetrics, Centro Hospitalar do AlgarvePortimão, Portimão, Portugal

\section{Correspondence to} Dr Vera Mourinha, vmourinha@gmail.com

Accepted 29 January 2016
CrossMark

\section{To cite: Mourinha $\mathrm{V}$}

Costa S, Urzal C, et al. BMJ Case Rep Published online: [please include Day Month Year] doi:10.1136/bcr-2015214338

\section{DESCRIPTION}

Aetiological diagnosis of genital ulcers is still a challenge in clinical practice. The cause is mostly infectious, but it may otherwise be a presentation of a wide variety of pathologies, such as autoimmune (eg, Behçet's disease), cancer or inflammatory processes.

The Lipschütz ulcer is a non-sexually transmitted condition. It has been considered as an uncommon and probably underdiagnosed entity, although a recent study has reported that it may represent around $30 \%$ of vulvar ulcerations. ${ }^{1}$ It affects mainly adolescents and young adults, but there are reported cases in children. It presents as a sudden onset of painful vulvar ulcers, usually wider than $1 \mathrm{~cm}$ and deep, with a red border and a necrotic centre covered by grey exudate or grey-black eschar, ${ }^{2}$ sometimes preceded by unspecific nongynaecological symptoms. Bilateral 'Kissing lesions' are characteristic. The diagnosis is mainly clinical and made by exclusion after ruling out other causes

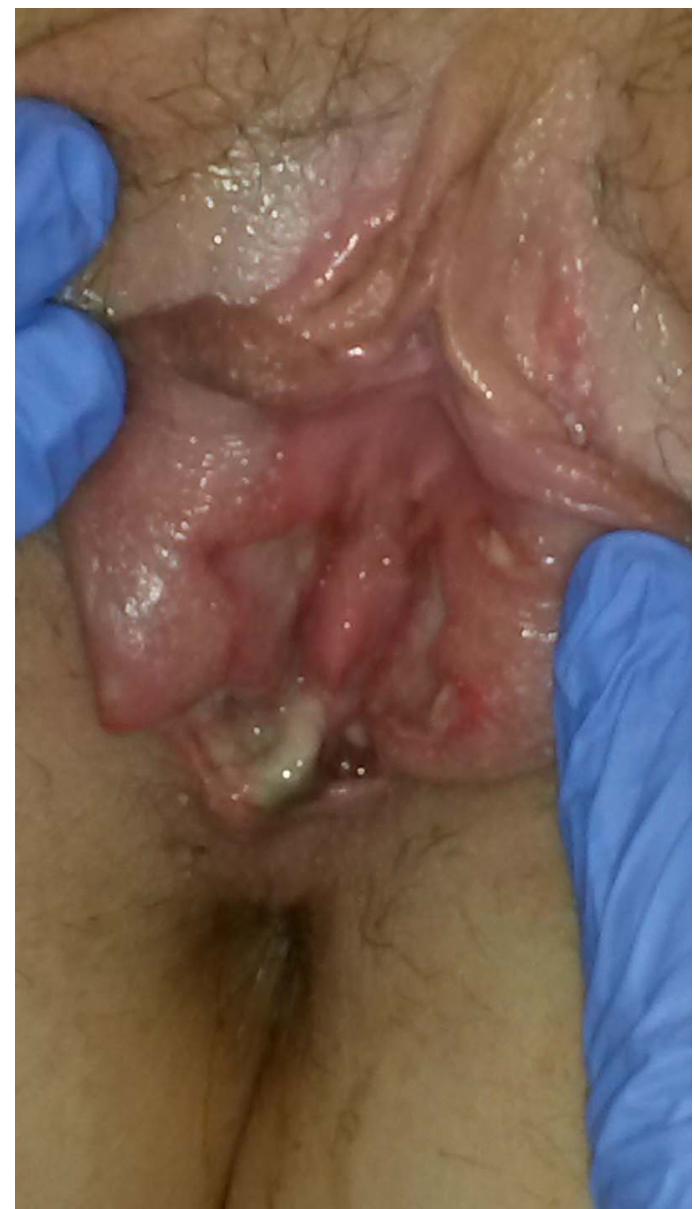

Figure 1 Large and deep ulcers with grey exudate and characteristic 'Kissing lesions'. of genital ulcerations. The aetiology is unknown, although some cases have suggested an association with acute Epstein-Barr virus (EBV) or other viral or bacterial infections. ${ }^{1-3}$

We report a case of a 22-year-old woman who presented at the emergency department, for painful extensive vulvar and lower vaginal ulcerations associated with greyish exudate and oedema (figures 1 and 2). It had started 3 days before, and the patient had been medicated with azithromycin, without improvement. She denied recent sexual intercourse, trauma and oral ulcerations, but referred a history of flu-like symptoms 1 week before. She was admitted for study and treatment, starting empiric treatment with doxycycline, acyclovir and analgesia (local and intravenous). Infectious (HIV, hepatitis C virus, hepatitis B virus, syphilis, herpes simplex virus, Varicella-Zoster virus, EBV and cultural tests) and autoimmune (antinuclear antibody, antiphospholipid antibodies, antineutrophil cytoplasmic antibody, C3 and C4 complement levels) tests

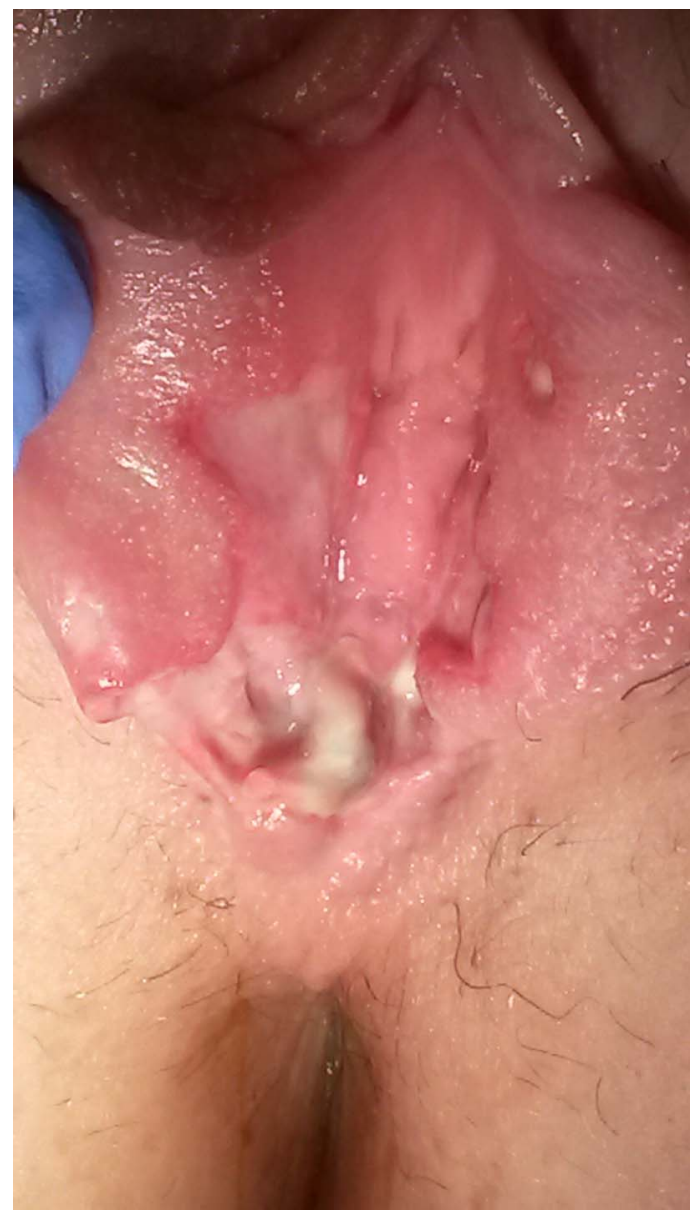

Figure 2 Multiple vulvar ulcers (first day after starting topical clobetasol). 


\section{Learning points}

- Lipschütz ulcers are uncommon and an often unknown entity for doctors, but it is important to recognise and include it in the differential diagnosis of vulvar ulcerations, and to make the diagnosis by exclusion.

- This condition is characterised by self-limited painful ulcerations of the vulva or lower vagina in adolescent or young women, non-sexually transmitted, and usually preceded by influenza or mononucleosis-like symptoms.

- Treatment is mainly supportive with pain relief (topical anaesthetics/oral analgesics) but, for multiple, large or deep necrotic ulcerations, topical or a short course of systemic corticosteroids may be considered. were negative. The patient was started on topical clobetasol. Complete healing occurred in about 3 weeks, with no scarring and no recurrence.

Contributors VM (wrote the article) and CU were the medical doctors responsible for the patient care during her hospitalisation. CU has been following up the patient in consultation since discharge. SC and FG contributed by discussing possible causes, tests and therapeutic options.

Competing interests None declared.

Patient consent Obtained.

Provenance and peer review Not commissioned; externally peer reviewed.

\section{REFERENCES}

1 Vieira-Baptista P, Lima-Silva J, Beires J, et al. Lipschütz ulcers: should we rethink this? An analysis of 33 cases. Eur J Obstet Gynecol Biol 2015.

2 Huppert JS. Lipschutz ulcers: evaluation and management of acute genital ulcers in women. Dermatol Ther 2010;23:533-40.

3 Sárdy M, Wollenberg A, Niedermeier A, et al. Genital ulcers associated with EpsteinBarr virus infection (ulcus vulvae acutum). Acta Derm Venereol 2011;91:55-9.

Copyright 2016 BMJ Publishing Group. All rights reserved. For permission to reuse any of this content visit http://group.bmj.com/group/rights-licensing/permissions.

BMJ Case Report Fellows may re-use this article for personal use and teaching without any further permission.

Become a Fellow of BMJ Case Reports today and you can:

- Submit as many cases as you like

- Enjoy fast sympathetic peer review and rapid publication of accepted articles

- Access all the published articles

- Re-use any of the published material for personal use and teaching without further permission

For information on Institutional Fellowships contact consortiasales@bmjgroup.com

Visit casereports.bmj.com for more articles like this and to become a Fellow 